\title{
Placenames of Scottish origins in Russia (a toponymic index and description)
}

\author{
Alexander Pavlenko - Galina Pavlenko - Olga Stroganova
}

\section{DOI: 10.18355/XL.2017.10.03.12}

\begin{abstract}
The article contains a brief description of a project devoted to the sociocultural interaction between Scotland and Russia and focusing on the toponyms derived from Scottish personal names found in the territory of the former Russian Empire. Although such placenames constitute a humble but a noteworthy part of the Scottish legacy in Russia, this stratum of the Russian toponymy has never been systematically studied. Here we provide a list of the Russian place-names of direct or indirect Scottish origins and summarize some observations regarding their history as well as the history of the families behind these names. A morphological analysis of the placenames of this kind is provided to reveal the word-building patterns involved.
\end{abstract}

Key words: Russia, Scotland, toponymy, placename, athroponym, morphological structure

\section{Introduction}

The anthropocentric approach to language in general and onomastics in particular allows to consider placenames through the history of the people and the histories of the idioms they speak. Toponymy of any country reflects the peculiarities of its historical development as well as cultural and language contacts taking place in its territory throughout the history. The problem of historical study of proper names has been addressed by scholars, who consider them as a kind of monuments "accumulating" history. This view is shared by such linguists as V.A.Nikonov (1965), A.I.Popov (1965), Yu.A.Karpenko (1970), A.V.Superanskaya (1985), E.M.Murzayev (1994), and others.

As has long been known, proper names may function as indicators of social processes and are sensitive to changes taking place in ethnic history. Therefore, in the historical study of onomastics, toponymy in particular, it is entirely natural to resort to a sociolinguistic approach (cf. Akhmanova 1967, Bondaletov 1970, Bakhnian 1981, Anikanova 1980, Ageyeva 1984). Indeed, the fact that placenames are by virtue an immediate manifestation of the social essence of language and as such constitute the most abundant group of onomastic vocabulary has been recognised by sociolinguists for a considerable period (cf. Akhmanova 1967: 79-80). Toponyms form the richest stratum of proper names and a vast subsystem within lexis.

The toponymy of Russia, in the course of its Europeanisation, accelerated by the Petrine reforms, was enriched by numerous placenames of Western-European origin. There were several ways for such onomastic novelties to appear, including several waves of immigration from the Western-European countries, directly or indirectly reflected in the toponymy. Yet, such later layer of the Russian toponymy as the derivatives of Western-European personal names as well as other types of placenames of Western-European origin has not received the attention it deserves.

The influx of foreign newcomers to Muscovite Rus' was observed as early as the late Middle Ages, but during and after the Petrine period it increased tremendously. The introduction of foreign cultural and linguistic elements to Russian soil could and, in fact, did cause the coinage of new geographical names of various types which were incorporated into the native Russian toponymic system and were

XLinguae Journal, Volume 10 Issue 3, June 2017, ISSN 1337-8384 
adopted by it. Not all of these toponyms were by any means able to survive the Soviet epoch with its passion for renaming. Some toponyms, moreover, were lost for various other reasons (including, for instance, change of land ownership, etc.), even before 1917.

The active participation of German and Dutch people in Russian history is widely acknowledged. Natives of the British Isles also left a conspicuous trace, and, although their influence on the Russian toponymy is very much weaker than the German one, it also deserves a special study.

Surprisingly, scholarly works dealing with the Western-European placenames in Russia are scarce, although its significance for the studies of cultural and linguistic contacts is unquestionable. We were able to find only few works dealing with the German toponymy of certain regions of Russia (Berend 1998; Dmitrieva 1987; Plewe 1995/1996; Sychialina 2008), and definitely nothing has been written about the Russian toponyms of British origins including the Scottish ones. The Russian place names of British origin are only very seldom mentioned in literature but have never been collected and/or described systematically.

Speaking about Britons in Russian service it is important to take into account their ethnicity (i.e. English, Scottish, Welsh or Irish), as neglecting this factor may not only impoverish the resulting picture of cultural and language interaction, but also lead to its distortion. Therefore we propose to study the toponyms in question while distinguishing their ethnic background.

Toponyms containing a certain English trace do exist in the territory of the former Soviet Union, although they are not numerous. They are mostly street names based on the names of the famous Englishmen and appeared in the Soviet epoch, e.g. ulitsa Nyutona (Newton street), ulitsa Darvina (Darwin street), ulitsa Shekspira (Shakespear street). In the rare toponym of Manchesterskaya ulitsa (Manchester street) there is a reference to an English city. Other place names may contain the attribute 'angliyskiy (-aya)' (i.e. English) as Angliyskaya naberezhnaya (i.e. English embankment) or Angliyskiy pereulok (i.e. English lane) and go back to the prerevolutionary epoch. However, there seems to be no oiconyms with English roots in the territory in question and in general the whole set of such toponyms produces an impression of being newer, less consistent, less numerous and less imbedded into the Russian historical and cultural context.

\section{Methodology}

We consider it expedient to summarise and study the Russian toponyms of Scottish origin first, i.e. any toponym containing a Scottish onomastic element (further TSO, i.e. toponyms of Scottish origin), because Scotland has been an independent team player in the vast region of Northern Europe and a very notable source of emigration to the cities and countries associated with the Hanseatic League, the Kingdom of Poland and the Grand Principality of Muscovy, which later transformed into the Russian Empire.

The first Scotsmen in Russia (designated as Shkotskie Nemtsy, literally "Scottish Germans") belonged to the military class and came to that country either as mercenaries or prisoners of war as long ago as the sixteenth century. Most of them were captured during the Livonian War in the reign of Ivan the Terrible and continued their military service beneath the Russian colours (Anderson 1990: 37).

Of course, as is well known, Russia was only one of a multitude of destinations which Scotsmen sought to reach. Scottish adventurers and professional soldiers considered the remote Russian lands to be a place where they could build their career and earn a living, if not a fortune. (cf. Murdoch and Grosjean 2005: 124).

Among the most recognisable names of "Russian" Scotsmen we can mention Peter I's generals and advisers Yakov Briuss (Bruce) and Patrick Gordon, the 
admiral Samuel Greig, the marshal of the 1812 war Mikhail Barclay de Tolly, the nineteenth century poet Mikhail Lermontov, and others who are less widely known. These were people of more or less remote Scottish descent, being either fresh immigrants retaining links with their country of birth or "umpteenth" generation Russian locals with just a part of Scottish blood in their veins. The late seventeenth and early eighteenth centuries saw the most abundant influx of Scots to Russia due to the Petrine reforms and a high demand for foreign professionals in all fields (Dukes 1987: 9-23; Cross 1987: 24-46). .

Their numerous achievements were not the only traces the Scots left in Russia. The toponyms derived from Scottish personal names constitute a humble but still a noteworthy part of Russia's Scottish heritage. As many of the Scots in Russian service were people of higher social rank and accomplishment their names were commemorated in the names of their estates and villages as well as in the names of streets in Russian urban and rural settlements. Unfortunately, most of these toponyms vanished in the Soviet epoch, with its passion for renaming based upon ideological considerations.

The villages of Briussovo, Gordonovo and Karrovo were named after generals Yakov (James) Bruce, Patrick Gordon and Vasiliy Kar (all of Scottish descent); the town of Lermontov bore the name of one of Russia's most celebrated lyrical poets; further not very numerous names of settlements of various sizes and geographical positions commemorate his name. Besides, there exists quite a number of odonyms - in fact nearly every town in Russia has a street named after Lermontov, whose Scottish ancestor George Learmonth is believed to have arrived in Russia as early as 1613 .

There exists one more strata of placenames whose Scottish origins appear to be less or altogether not obvious. We will name this type of source of toponyms as "hidden" or "covert".

In the vernacular the altered foreign surnames were likely to lose their original appearance practically altogether. These names were usually likened to a Russian word, which was relatively close to the etymon in terms of sound. People's imagination strived to see a familiar root in the foreign name, making this phenomenon not unlike folk etymology, based on wishful thinking attempting to find familiar features in an unfamiliar word. It seems that the more complicated or bizarre a foreign surname sounded to the Russian ear and the more complex its morphological structure was, the more likely it would be to undergo a complete re-association.

A peculiar example of how a Scottish anthroponym might be reflected in Russian toponymy is the fate of the surname of Hamilton transformed in a multitude of ways on the Russian soil - from Gamantov to $100 \%$ Russian Khomutov, likened to khomut (Rus. horse collar).

The fact that this element of Russian toponymy has never been systematically studied makes a retrospective look at the history of such placenames indispensable. We have tried to discover and summarize all the placenames of direct or indirect (covert or overt) Scottish origins on the territory of the former Russian Empire (excluding Poland, Finland and today's Baltic states) and to trace back the history of such Scottish names as well as the history of the persons or/and the families who are behind these names. It was also necessary to consider the fact that some settlements and streets have been renamed, consigning their historical names of Scottish origin to oblivion. Renaming might have been a result either of change in the ownership of a serf village in the Russian Empire or the enthusiasm of Communist activists early in the twentieth century.

Therefore our approach can be generalised in just one pattern: from personal name(s) to placenames. It combines the use of biographies, maps (including interactive ones), as well as regional geographical and historical descriptions. We 
based our search on such authoritative sources on the Scottish-Russian historical ties as Anderson 1990; Cross 1987; Dukes 1987; Fedosov 1996, as well as some other resources. The practical outcome of the study is intended to be a reliable glossary of Russian toponyms of Scottish origins accompanied by a general overview and analysis.

\section{The index of Russian toponyms of Scottish origins}

The toponyms have been selected partly by means of analyzing biographies of notable historical figures with Scottish roots and partly by the focused search of the maps. We have presently been able to record 46 toponyms of several types (see Table 1 below):

\begin{tabular}{|c|c|}
\hline 1. & Barklaevskaya, ulitsa (street) St. Petersburg, Russia \\
\hline 2. & $\begin{array}{l}\text { Barklaya de Tolli, ulitsa (street), Kaliningrad, Kaliningradskaya } \\
\text { oblast', Russia }\end{array}$ \\
\hline 3. & $\begin{array}{l}\text { Barklaya de Tolli, ulitsa (street), Smolensk, Smolenskaya oblast', } \\
\text { Russia }\end{array}$ \\
\hline 4. & $\begin{array}{l}\text { Bryusovo (village), also Glinki, also Bogoslovskoye; Schiolkovskiy } \\
\text { district, Moscow region }\end{array}$ \\
\hline 5. & $\begin{array}{l}\text { Bryusovo (smaller town/settlement) - former Germ. Uschblenken; } \\
\text { Oziorskiy district, Kaliningradskaya region }\end{array}$ \\
\hline 6. & Bryusov (district/neighbourhood) - the city of Yerevan, Armenia \\
\hline 7. & Bryusovskaya, ulitsa (street) - St.-Petersburg, Russia \\
\hline 8. & Bryusov, pereulok (lane) - Moscow, Russia \\
\hline 9. & $\begin{array}{l}\text { Cameronian (Russified Kameronova) galleria (monument of } \\
\text { architecture) - Yekaterininskiy park, the town of Pushkin, } \\
\text { municipal town in Pushkinsky District, the federal city of } \\
\text { St. Petersburg, Russia }\end{array}$ \\
\hline 10. & $\begin{array}{l}\text { Dounkin (later Doun'kin) (pereulok) (today's Krestyanskiy } \\
\text { Pereulok) }- \text { St. Petersburg, Petrogradskiy district, Russia }\end{array}$ \\
\hline 11. & $\begin{array}{l}\text { Edinburgskaya, ulitsa (i.e. Edinburgh street) - a newly built } \\
\text { townhouse estate "Malen'kayaShotlandiya" (Little Scotland) in } \\
\text { between village Pikino and settlement Luniovo, Solnechnogorskiy } \\
\text { district, Moskovskaya oblast' }\end{array}$ \\
\hline 12. & $\begin{array}{l}\text { (?)Gomontovo (village) (also previously Gamutova, Gomantova, } \\
\text { Gomantovo, Gomontova, Khomuta, Gamontova) - Volossovskiy } \\
\text { district, Leningradskaya oblast', Russia. }\end{array}$ \\
\hline 13. & Gordonovo (village) - Orlovskaya oblast', Russia \\
\hline 14. & $\begin{array}{l}\text { Greygovo (Ukr. Hreyhove) (smaller town/settlement) - Zhovtnevy } \\
\text { district, Nikolayevskaya (Ukr. Mykolayivs'ka) oblast', Ukraine }\end{array}$ \\
\hline 15. & $\begin{array}{l}\text { Institute for Ethnology and Anthropology named after N.N. } \\
\text { Miklukho-Maklay (Institution within the Russian Academy of } \\
\text { Sciences)-Moscow, Russia }\end{array}$ \\
\hline 16. & $\begin{array}{l}\text { Karrovo (also Goriainovo, also Serghievskoye, also today's } \\
\text { Kol'tsovo) (village) - Kaluzhskaya oblast', Russia }\end{array}$ \\
\hline 17. & $\begin{array}{l}\text { Khomutovo (Ukr. Khomutove) (village) Novoazovs'kiy district, } \\
\text { Donetsk oblast', Ukraine }\end{array}$ \\
\hline 18. & $\begin{array}{l}\text { Khomutovskaya (stanitsa - Kossack village) Kagalnitskiy district, } \\
\text { Rostovskaya oblast', Russia }\end{array}$ \\
\hline 19. & $\begin{array}{l}\text { Khomutovskaya step' (natural reserve) Novoazovsk } \\
\text { Novoazovs'k) district, Donetsk oblast', Ukraine }\end{array}$ \\
\hline 20. & $\begin{array}{l}\text { Khomutovskoye Shosse (street) stanitsa Kirovskaya, Kagalnitskiy } \\
\text { district, Rostovskaya oblast', Russia }\end{array}$ \\
\hline
\end{tabular}




\begin{tabular}{|c|c|}
\hline 21. & $\begin{array}{l}\text { Khomutovskiy prospect (today's Bakunin street) Novocherkassk, } \\
\text { Rostovskaya oblast', Russia }\end{array}$ \\
\hline 22. & $\begin{array}{l}\text { Kropotovo-Lermontovo (village) } \\
\text { Lipetskaya oblast', Russia }\end{array}$ \\
\hline 23. & $\begin{array}{lllll}\text { Lermontova ploschiad' } & \text { (square) }- & \text { town } & \text { Ghelendzhik, } \\
\text { Krasnodarskiy kray, Russia } & & & & \\
\end{array}$ \\
\hline 24. & $\begin{array}{l}\text { Lermontova ploschiad' } \quad \text { (square) }- \text { town Karabanovo, } \\
\text { Aleksandrovskiy district, Vladimirskaya oblast', Russia }\end{array}$ \\
\hline 25. & Lermontovskaya ploschiad' - Moscow, Russia \\
\hline 26. & Lermontov (town of krai significance) - Stavropol Krai, Russia \\
\hline 27. & Lermontovo (Russian village) - Lori region, Armenia \\
\hline 28. & $\begin{array}{l}\text { Lermontovka (village), Bikinskiy district, Khabarovskiy krai, } \\
\text { Russia }\end{array}$ \\
\hline 29. & $\begin{array}{l}\text { Lermontovka (village), Tambovskiy district, Amurskaya oblast', } \\
\text { Russia }\end{array}$ \\
\hline 30. & $\begin{array}{l}\text { Lermontovka (disappeared village- } 2 \text { households, } 5 \text { inhabitants), } \\
\text { (before } 1948 \text { Crimea Tat. Ac1 Eli Q1pçaq) Belogorskiy district, } \\
\text { Autonomous Republic of the Crimea, Russia }\end{array}$ \\
\hline 31. & $\begin{array}{l}\text { Lermontovo (village) Seryshevskiy district, Amurskaya oblast', } \\
\text { Russia }\end{array}$ \\
\hline 32. & $\begin{array}{l}\text { Lermontovo (settlement) Bagrationovskiy district, Kaliningradskaya } \\
\text { oblast', Russia }\end{array}$ \\
\hline 33. & $\begin{array}{l}\text { Lermontovo (settlement) Gusevskiy district, Kaliningradskaya } \\
\text { oblast', Russia }\end{array}$ \\
\hline 34. & $\begin{array}{l}\text { Lermontovo (smaller town/settlement within Greater Kaliningrad) } \\
\text { Kaliningrad, Kaliningradskaya oblast', Russia }\end{array}$ \\
\hline 35. & $\begin{array}{l}\text { Lermontovo (village) Podosinovskiy district, Kirovskaya oblast', } \\
\text { Russia }\end{array}$ \\
\hline 36. & $\begin{array}{l}\text { Lermontovo (village) Tuapsinskiy district, Krasnodarskiykrai, } \\
\text { Russia }\end{array}$ \\
\hline 37. & $\begin{array}{l}\text { Lermontovo (village) Belinskiy district, Penzenskaya oblast', } \\
\text { Russia }\end{array}$ \\
\hline 38. & $\begin{array}{l}\text { Lermontovo (village) (village named after Ilyas Omarov since } \\
\text { 2012) Altynsarin district, Kostanay region, Kazakstan }\end{array}$ \\
\hline 39. & $\begin{array}{l}\text { Leslievo (village) allegedly today's village Miropol', } \\
\text { Malovyskovskiy district, Kirovogradskaya oblast', Ukraine (former } \\
\text { Elisavetgradskiy uyezd, Khersonskaya guberniya, Russian Empire }\end{array}$ \\
\hline 40. & Marr street (street) a street in Tbilissi, the capital of Georgia. \\
\hline 41. & $\begin{array}{l}\text { Marr street (street) a street in Sukhum, the capital of Abkhazia } \\
\text { (former Enghels street). }\end{array}$ \\
\hline 42. & $\begin{array}{l}\text { Mekenzievy Gory (i.e. mountains) (the heights in the northern part } \\
\text { of Sevastopol'; the initial part of the inner range of the Crimean } \\
\text { Mountains), Sevastopol' city, Russia }\end{array}$ \\
\hline 43. & $\begin{array}{l}\text { Mekenzievy Gory (railway station in the northern part of } \\
\text { Sevastopol' on the Sevastopol'-Simpheropol' track-section) } \\
\text { Sevastopol' city, Russia }\end{array}$ \\
\hline 44. & $\begin{array}{l}\text { Mekenzievy Gory (cemetery) Nakhimov district, Sevastopol' city, } \\
\text { Russia }\end{array}$ \\
\hline 45. & $\begin{array}{l}\text { Mekenzievy Gory (Sevastopol''s neighbourhood adjacent to } \\
\text { Mekenzievy Gory railway station) Sevastopol' city, Russia }\end{array}$ \\
\hline 46. & $\begin{array}{l}\text { (?) Miklukho-Maklaya, ulitsa (street) - Yugo-Zapadnyi (South- } \\
\text { Western) administrative district, Moscow, Russia }\end{array}$ \\
\hline
\end{tabular}

XLinguae Journal, Volume 10 Issue 3, June 2017, ISSN 1337-8384 


\section{Table 1. The index of Russian toponyms of Scottish origins}

The entries are presented in alphabetical order. Different kinds of toponyms have been placed together - names of setllements, streets, individual architectural objects, localities, etc. Some family names need additional commentary. One should distinguish the toponyms going back to the Russian branch of the Briuss (Bruce) family and those produced from the surname "Briussov" (in other words Briuss's, in Russian, which is a genitive form). The latter was obviously derived from the former and originally used to be given to the peasant serfs belonging to the landowners, the Briusses. Several toponyms were coined to commemorate the prominent Russian poet of the "Silver Age" Valeriy Briussov, who had a peasant background. Because the name "Briussov" is a derivative, however, we consider toponyms going back to it as an overt manifestation of Scottish influence because of its clear and direct connection with the basic form of "Briuss" < "Bruce".

As has already been mentioned, another important surname is "Lermontov". This name is extremely productive in coining toponyms what is caused by the significance of the figure behind it, i.e. the poet M.Yu.Lermontov, who lived in the first half of the nineteenth century and whose Scottish ancestry is common knowledge. Nearly every Russian city and town has a street or lane or square named after someone generally considered the second greatest Russian poet after Pushkin. Lermontov's independent behavior and attitudes towards the society of his time made him very popular with the Soviet authorities who blanketed the country with streets named after him and monuments erected in his honour. Besides, several urban and rural settlements were named after him. Therefore we take for granted the fact that scores of streets bear Lermontov's name, and consider only the names of settlements and squares here.

\section{Analysis and discussion}

The toponyms listed above fall into the following groups or categories:

1. the names of towns, villages and other types of settlements (i.e. oiconyms), e.g. Greygovo (Rus. Грейгово; Ukr. Грейгове);

2. the names of streets (including lanes, etc.) (odonyms), e.g. Barklaevskaya ulitsa (Rus. Барклаевская улица), the names of squares (agoronims), e.g. Lermontovskaya ploschiad' (Rus. Лермонтовская площадь);

3. the names of districts and neighbourhoods, e.g. Mekenzievy Gory (Rus. Мекензиевы Горы);

4. the names of individual architectural features (and infrastructural objects (e.g., institutions), e.g. Cameronian Gallery (Rus. Камеронова галерея);

5. the names of natural features such as mountains or heights (oronyms) and terrains, e.g. Khomutovskaya step' (Rus. Хомутовская степь).

This distribution of TSO along with the corresponding quantitative data are presented in Table 2.

\begin{tabular}{|l|l|l|l|l|}
\hline $\begin{array}{l}\text { Names of } \\
\text { settlements }\end{array}$ & $\begin{array}{l}\text { Names of streets, lanes, } \\
\text { squares and other objects } \\
\text { within settlements }\end{array}$ & $\begin{array}{l}\text { Names of } \\
\text { individual } \\
\text { buildings and } \\
\text { infrastructural } \\
\text { objects }\end{array}$ & $\begin{array}{l}\text { Names of } \\
\text { natural } \\
\text { features }\end{array}$ \\
\hline
\end{tabular}




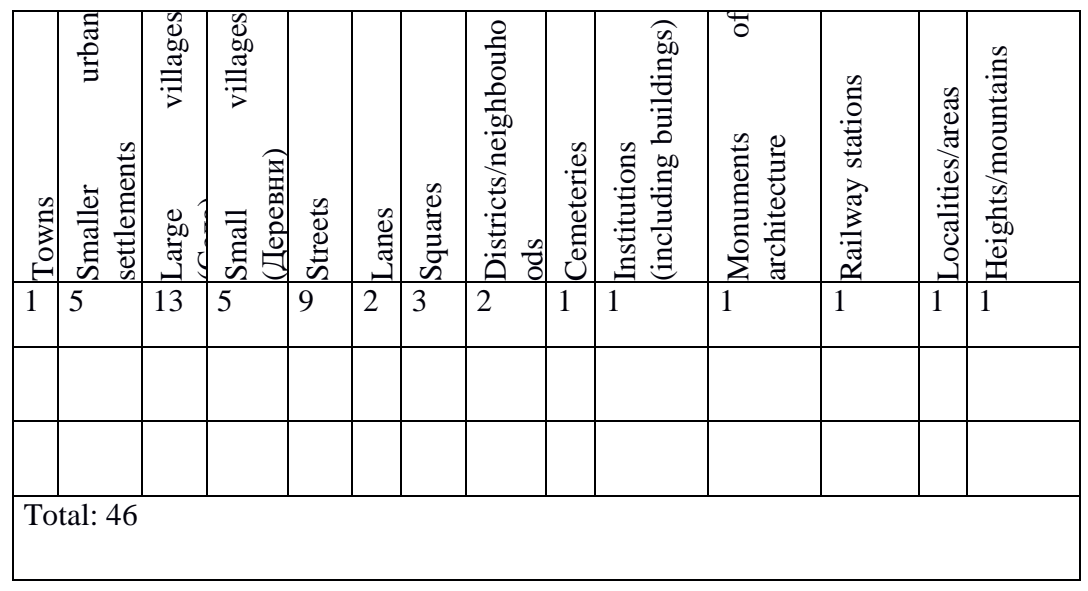

\section{Table 2. Distribution of toponyms according to the types of the objects referred} to.

Thus, names of rural settlements and streets are the most numerous features bearing TSO, what is understandable because they seem to be not merely the most numerous objects as such but also the most conservative ones in historical and toponymical respect. Many other types outside this set are represented just by single examples what does not allow to speak of any systemic correlations.

Nearly all TSO turned out to be anthroponyms derived from personal names with high or low level of distortion caused by assimilation in the recipient language.

The identified toponyms may also be subdivided into:

1. The toponyms derived directly from Scottish personal (family) names in their more or less correct transcription (e.g. Bruce (personal name) > Briussovo (placename); Gordon (personal name) > Gordonovo (placename));

2. The toponyms derived from the Scottish personal names which underwent reinterpretation or rethinking on the Russian soil (e.g. Hamilton (personal name) $>$ Khomutov (personal name) $>$ Khomutovo (placename));

3. Directly borrowed Scottish placenames or their derivatives. The derivatives of Scottish placenames or their direct borrowings started to appear only very recently (unlike those of German origin) what can be explained by the peculiarities of immigration of Scots to Russia as compared to that of Germans. The toponyms of this kind appear due to the general public interest in Scotland and its culture and are represented by scarce urbanonyms derived from or containing the names of, say, iconic Scottish places, twin-cities, etc., etc. and designate newly built streets, parks and luxury housing estates (e.g. Malen'kaya Shotlandiya (Little Scotland), a housing estate $16 \mathrm{~km}$ from Moscow).

The analysis of the primary material also allows us to judge on whether:

- the toponym under consideration is an allonym (a primary or secondary (alternative)) one;

- $\quad$ it is modern or historical/obsolete;

- it is official or non-official/colloquial;

- $\quad$ it is overt or covert/hidden. 
As an example of answering all these questions regarding an individual toponym we propose Table 3 considering the placename "Karrovo" (Kaluga oblast' "region") derived from the personal name "Kar".

\begin{tabular}{|c|c|c|c|c|c|c|c|c|c|c|c|c|c|c|c|}
\hline \multicolumn{16}{|c|}{ Karrovo } \\
\hline \multicolumn{2}{|c|}{$\begin{array}{l}\text { Type of } \\
\text { toponym }\end{array}$} & \multicolumn{4}{|c|}{$\begin{array}{l}\text { Names of } \\
\text { settlements }\end{array}$} & \multicolumn{6}{|c|}{$\begin{array}{l}\text { Names of streets, lanes, } \\
\text { squares and other objects } \\
\text { within settlements }\end{array}$} & \multicolumn{2}{|c|}{$\begin{array}{l}\text { Names of } \\
\text { individual } \\
\text { buildings } \\
\text { and } \\
\text { infrastructu } \\
\text { ral objects }\end{array}$} & \multicolumn{2}{|c|}{$\begin{array}{l}\text { Names of } \\
\text { natural } \\
\text { objects }\end{array}$} \\
\hline \multirow{2}{*}{\multicolumn{2}{|c|}{$\begin{array}{l}\text { Type of } \\
\text { toponym }\end{array}$}} & \multicolumn{4}{|c|}{$\begin{array}{l}\text { Names of } \\
\text { settlements }\end{array}$} & \multicolumn{6}{|c|}{$\begin{array}{l}\text { Names of streets, lanes, } \\
\text { squares and other objects } \\
\text { within settlements }\end{array}$} & \multicolumn{2}{|c|}{\begin{tabular}{|l} 
Names of \\
individual \\
buildings \\
and \\
infrastructu \\
ral objects \\
\end{tabular}} & \multicolumn{2}{|c|}{$\begin{array}{l}\text { Names of } \\
\text { natural } \\
\text { objects }\end{array}$} \\
\hline & & $\sum_{0}^{n}$ & 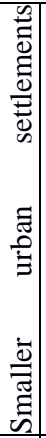 & 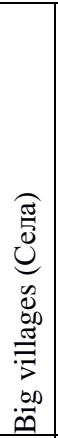 & 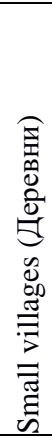 & 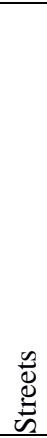 & 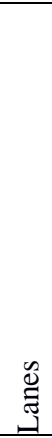 & 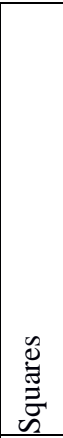 & 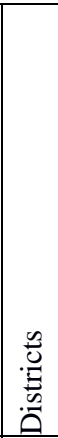 & $\frac{\mathscr{Q}}{\mathbb{E}}$ & 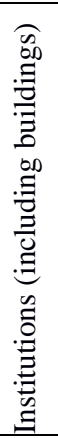 & 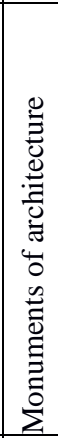 & 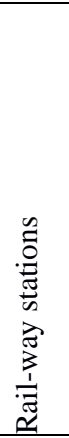 & 总 & 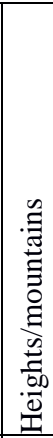 \\
\hline \multicolumn{2}{|c|}{$\begin{array}{l}\text { Status of } \\
\text { toponym }\end{array}$} & & & & + & & & & & & & & & & \\
\hline \multirow{3}{*}{ 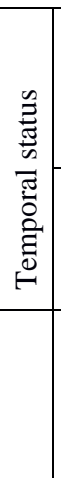 } & 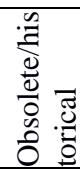 & & & & + & & & & & & & & & & \\
\hline & $\overrightarrow{0}$ & & & & & & & & & & & & & & \\
\hline & 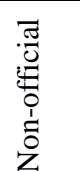 & & & & + & & & & & & & & & & \\
\hline
\end{tabular}




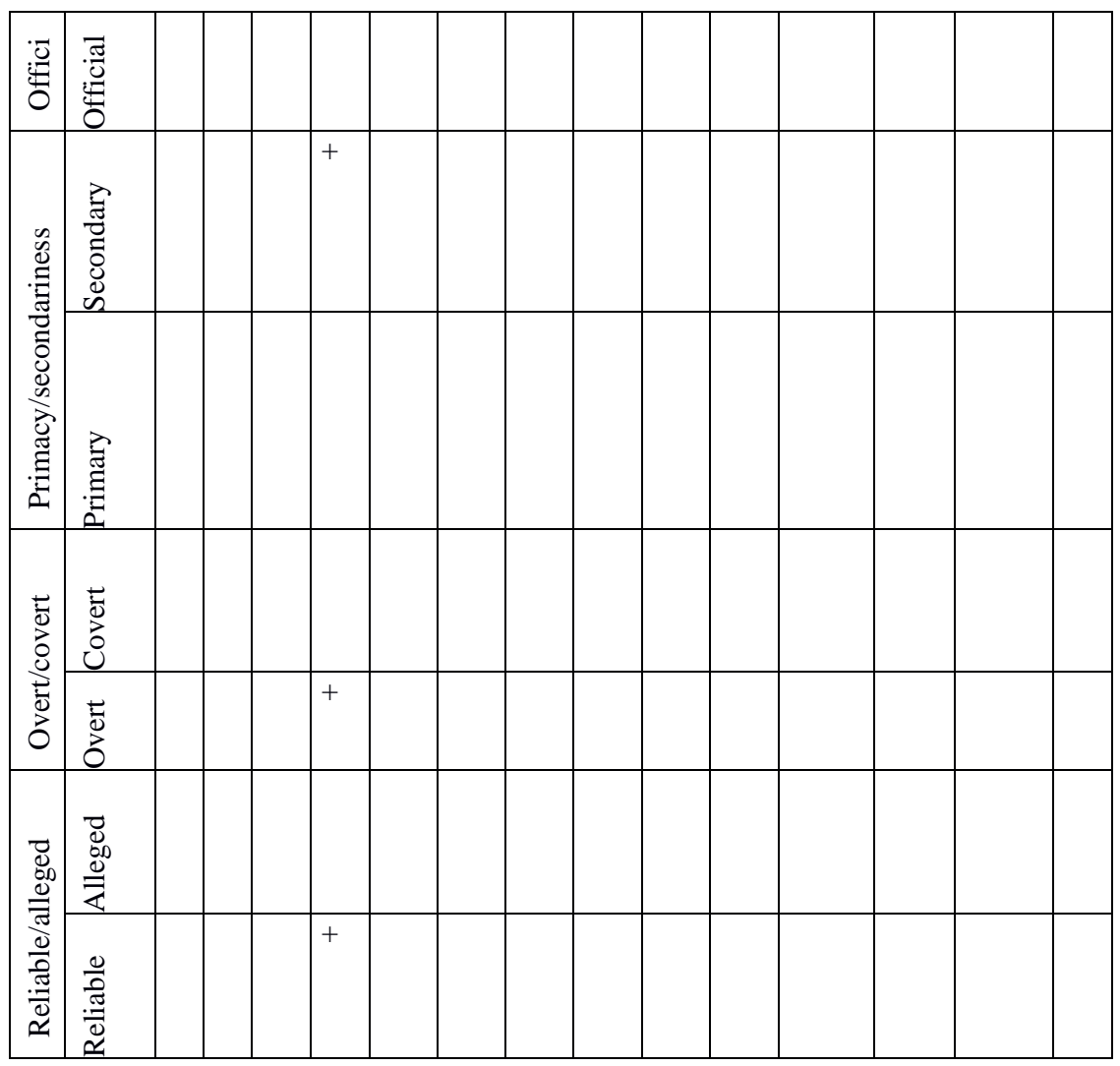

Table 3. Status of an individual toponym according to the peculiarities of its use

Table 3. demonstrates that the village of Karrovo is a toponym reliably characterized as TSO; it is overt, as it is easily and reliably traced to its etymon "Kar", which did not undergo rethinking or resemantisation or even was not seriously phonetically distorted. It is characterised as a "secondary" allonym because it historically follows the toponyms of "Goriainovo" and "Serghievskoye". It does not have an official status today as the village is designated as "Kol'tsovo" today. In fact, being an alternative name the toponym in question must have been "semi-official" even in its "best" times. However, it was used in an official registry. Finally it can be characterised as historical or obsolete today as it is no longer actively employed.

Not all the collected TSO have undergone this procedure so far because reliable information can only be obtained in some cases on the spot what demands archive and field work in several regions of Russia and beyond.

\section{The planned outcome}

On completion of the study a glossary must appear consisting of more or less compact but informative entries. The entries are supposed to contain the information on 1) the type of the feature bearing the placename; 2) its geographical position; 3) the allonyms if any, as well as their historical sequence; 4) the historical description of the name taking into account all the aspects of the etymon the TSO goes back to; 5) the 
status of the TSO (see Table 2); 6) some entries may be supplied with pictures or even maps.

\section{"Karrovo".}

Here you can see a sample of the draft entry dealing with the TSO

A sample entry

Karrovo, village (also Goriainovo (the original name), also Serghievskoye, also (in and after the Soviet epoch) Kol'tsovo) situated in Kaluga region. The village used to belong to the noble Golitsyn family. It was the main settlement of their estate also comprising the villages of Alferyevo, Dmitrovka, Kashurki, Polivanovo, Pyshkovo and Shakhovo. The estate was bought by Vasiliy Alexeyevich Kar, who was of Scottish ancestry, at an auction in 1775 (cf. Kaluzhskaya Encyclopedia 2005, articles 'Kar', 'Kol'tsovo').

The family mansion in Goriainovo was originally made of wood but after it had been acquired by Kar, a grandiose construction project was launched. Although it had not been completed either by the Kars or by the later owners (the Ossorghin family) the buildings and the park were said to be very impressive.

Vasiliy Alexeyevich Kar laied out a vast park and built a large and robust mansion looking more like a castle. It was known to have secret stairs, spacious cellars and even an underground tunnel leading to the bank of the Oka river. Among the local peasants there was a strong belief that their master had some dark mystery in his previous life to hide; he might have made his fortune in an improper way and been afraid of something, possibly a vengeance. Vassiliy Alexeyevich Kar was said to be a cruel master to his serfs, with dozens of them having lost their lives when building the estate. At the same time, however, he rationalised farming techniques on his lands and enjoyed everybody's acclaim in the then Kaluga province as a successful and prosperous landlord.

The rumours surrounding the figure of Kar were not unjustified. His very acquisition of the estate along with Goriainovo followed his disgrace during Emelian Pugatschiov's rebellion in 1773. Being a Major-General of the Russian army he was commissioned by Catherine II to cope with the rebels. However, no sooner had Kar arrived at his headquarters in Orenburgh province, than he left his troops and came back to Moscow, what was interpreted by society as negligence if not cowardice. Catherine dismissed Kar from military service by her order and forbade him to live in either Saint-Petersburg, the then capital, or Moscow. Those dramatic events were described by Pushkin in his 'Account of Pugachiov's rebellion' what made Kar's allegedly improper behaviour known even wider. However, there was also a view that Kar became a victim of court intrigues and was made responsible for all the initial mistakes and unsuccessful actions against Pugachiov (Doubrovin 1884: 62-166). In any event, this was the troubled background to his becoming the owner of Goriainovo.

Vasiliy Alexeyevich Kar (1730/32?) belonged to an old Scottish dynasty (Fedosov 1996: 19). His great grandfather Thomas arrived in Moscow in the early $16^{\text {th }}$ c. along with his brothers John and Robert to serve Czar Mikhail Romanov. His brothers' further fate is unknown. For his true service Thomas (or 'Foma Ivanovich' in Russian) was granted an estate in Nizhniy-Novgorod province. He had three sons, Vasiliy, Phillip and Matfey. Phillip Kar, Vassiliy Alexeyevich's grandfather, who became a colonel, also had three sons: Afanasiy, Alexey and Ivan.

Alexey Philipovich Kar (1680-1756), General Kar's father, participated in Peter I's principal campaigns and reached the rank of major. Later, having retired, he served as head of the Salt Office. 


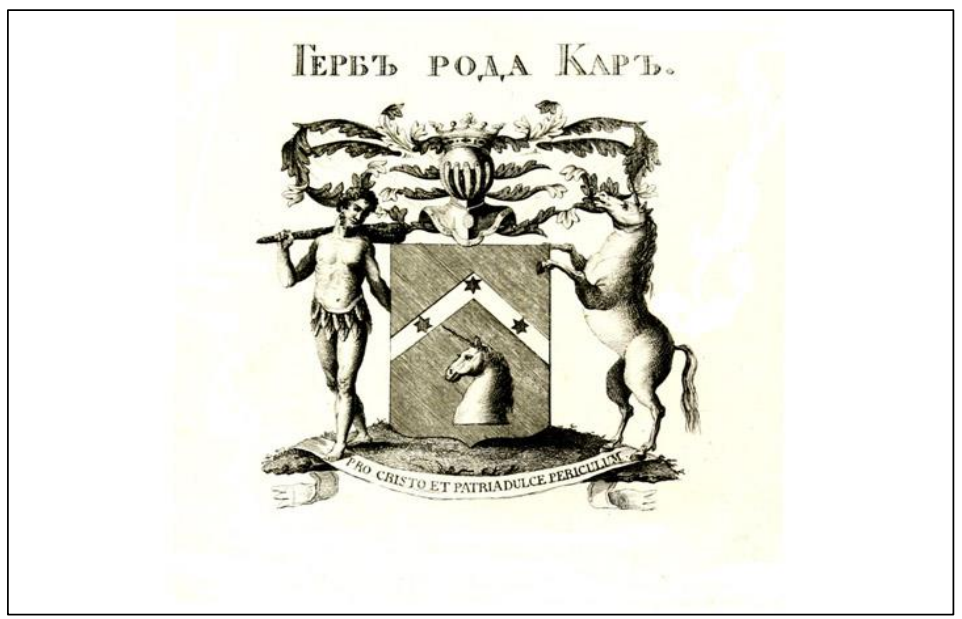

\section{Figure 1: The Kars' coat of arms.}

Vassiliy Alexeyevich Kar died in either 1805 or 1806 and the estate was inherited by his wife Maria Sergheyevna Kar, née Khovanskaya. After her death in 1833 her younger son Serghey became the owner. The elder son Alexey was previously disinherited by his father for mean behaviour.

Serghey Kar renamed his principal village as Serghievskoye. He also changed his surname to Karro possibly because of his father's widely known disgrace during Catherine's reign. Serghey Vassiliyevich Kar was also said to be extremely cruel with his serfs. In 1843 he lost all his estates at cards to M.G.Ossorghin (cf. Shmemann 1997), and the Ossorghin family remained the owners of the estate until the advent of the Soviet power.

In general, the Kars owned the estate and the village of Goriainovo / Karrovo / Serghievskoye for 68 years having contributed substantially both to its physical appearance and social history.

In the course of compiling such entries it is intended to accompany the abovementioned historical insight both with etymological and some morphological analysis in order to supply the entry with sufficient information on the word-building types characteristic of the Russian toponymy as well as the patterns of Russification involved. Therefore, it is planned to include a brief reference on morphology of the types of Russian family- and placenames in the introduction.

\section{Conclusion}

We finally have to stress once again that as regards most older rural settlements bearing historical names with a Scottish element (except the multitude of places named after Lermontov, of course) they were designated this way rather by their inhabitants, who thus recognised that this or that village was in the possession of their master - a local landlord. Of course, serfs might have known next to nothing about the exact country his or her ancestors came from. It is likely that most of the scarce Russian rural toponyms of Scottish origin have never been the principal or the only names of the settlements. At the same time at least some of them were entered into the official registry books in the nineteenth century. These toponyms were used as mere alternative or secondary placenames and most of them have been doomed to oblivion. Therefore, while the general approach and the individual techniques seem to be clear, 
there remains a no less important problem, i.e. to make sure that all the placenames of Scottish origins have been revealed, and to trace their human and historical background.

Discussing the Scottish trace in the toponymy of Russia one should bear in mind that the number of these placenames is relatively modest, especially in comparison with that of the German ones, nevertheless it is far from being immaterial and seems to exceed the toponyms of English origin.

\section{Bibliographic references}

AGEYEVA, R.A. 1984. Sotsiolingvisticheskiy aspekt imeni sobstvennogo. Nauchnoanaliticheskiy obzor. Ed. by F.M. Berezin. Moscow: INION IN USSR (in Rusian)

ANDERSON, I.G. 1990. Scotsmen in the service of the Czars. Edinburgh: The Pentland Press. ISBN 0-946270-74-0

AKHMANOVA, O.S. 1967. Toponimika kak sotsiolingvisticheskaya problema (na materiale novykh naimenovaniy). In: Filologicheskiye nauki, No.6. Ed. by: Akhmanova O.S., Belen'kaya V.D., pp. 79-89 (in Russian)

ANIKANOVA, T.A. 1980. K voprosu o sotsiolingvisticheskoy prirode ograficheskikh nazvaniy. In.: Voprosy teorii I metodiki prepodavaniya inostrannykh yazykov. Moscow: Nauka publishing. pp. 52-56 (in Rusian)

BAKHNIAN, K.V. 1981. Sotsiolingvisticheskiy analiz antroponimov. In.: Teoreticheskie problemy sotsialnoy linguistiki. Ed. by Yu.D. Desheriev. Moscow: Nauka publishing. pp. 305-324 (in Russian)

BEREND, N. 1998. Sprachliche Anpassung. Eine soziolinguistisch-dialektologische Untersuchung zum Russlanddeutschen . Tubingen: Gunter Narr Verlag. ISBN-10: 3823351443; ISBN-13: 978-3823351443

BONDALETOV, V.D. 1970. Onomastika i sotsiolinguistika. In: Antroponimika. Ed. by: V.A. Nikonov and A.V. Superanskaya. Moscow: Nauka publishing. pp. 17-23 (in Russian)

CROSS, A.G. 1987. Scoto-Russian Contacts in the Reign of Catherine the Great (1762-1796). In P.Dukes (ed.) The Caledonian Phalanx. Scots in Russia. Edinburgh: National Library of Scotland. pp. 24-46. ISBN 0-902220-88-8

DMITRIEVA, L.M. 1987. Slozhnyye nemetskiye toponimy na Altaye v usloviyakh russko-nemetskogo vzaimodeystviya. Collection of works. Ed. By A.K. Matveyev. Sverdlovsk: UrGU Publishing House. pp. 141-145 (in Russian)

DOUBROVIN, N. 1884. Pougachiov I ego soobschniki: Epizod iz istorii tsarstvovaniya imperatritsy Ekateriny II. V.2. S.Petersburg: Tipografia I.N. Skorokhodova (in Russian)

DUKES, P. 1987. Scottish Soldiers in Muscovy. In P.Dukes (ed.) The Caledonian Phalanx. Scots in Russia. Edinburgh: National Library of Scotland. pp. 9-23. ISBN 0902220-88-8

FEDOSOV, D. 1996. The Caledonian Connection. Scotland-Russia Ties - Middle Ages to Early Twentieth Century (A concise biographical list). Aberdeen: Centre for Scottish Studies - University of Aberdeen. ISBN 0906265223

FILIMONOV, V. (Ed.). 2005. Kaluzhskaya Encyclopedia. Kaluga: N.F.Bochkariova's Scientific Literature Publishing house. ISBN 5-89552-333-1 (in Russian)

KARPENKO, Yu.A. 1970. Istoriya Etimologicheskogo Metoda v Otechestvennoy Toponimike. In: Razvitie Metodov Toponimicheskikh Issledovaniy. Moscow: Nauka Publishers (in Russian)

MURDOCH, S. - GROSJEAN, A. 2005. Introduction. In: Grosjean A., Murdoch S. (Eds.) Scottish Communities abroad in the early Modern Period. Studies in medieval and Reformation traditions. History, Culture, Religion, Ideas. Vol. CVII. Brill, Leiden - Boston, pp. 1-24. ISBN 900414306 8; ISSN 1573-4188 
MURZAYEV, E.M. 1994. Russkaya Onomastika I Onomastika Rossii. Moscow: Shkola-Press Publishers. ISBN: 5-88527-066-x (in Russian)

NIKONOV, V.A. 1965. Vvedenie v Toponimiku. Moscow: Nauka publishing. (in Russian)

PLEWE, J. 1995/1996. Die ersten deutschen Ortsnamen an der Wolga. In: Heimatbuch 1995/1996. Landsmannschaft der Deutschen aus Russland. Stuttgart: Landsmannschaft der Deutschen aus Rußland. ss. 276-278. ISBN-10: 3923553110; ISBN-13: 978-3923553112

POPOV, A.I. 1965. Geograficheskiye Nazvaniya. Moscow-Leningrad: Nauka publishing (in Russian).

Shmemann, S. 1997. Echoes of a Native Land. Two Centuries of a Russian Village. New York: Alfred A. Knopf. ISBN-13: 9780679757078

SUPERANSKAYA, A.V. 1985. Chto Takoye Toponimika. Moscow: Nauka Publishing (in Russian)

SYCHIALINA, E.V. 2008. Nemetskaya toponymiya Povolzhya: sotsiolingvisticheskiy aspect issledovaniya (an unpublished $\mathrm{PhD}$ dissertation). Saratov: Saratov State University (in Russian)

This article is published with the support of the Royal Society of Edinburgh and the Caledonian Research Foundation.

Words: 5139

Characters:30 438 (15,22 standard pages)

assoc.prof., DrSc. Alexander Pavlenko

Department of English

Faculty of Foreign Languages

A.P. Chekhov Institute of Taganrog

(branch of) Rostov State University of Economics (RINH)

48, Initsyativnaya street, 347936, Taganrog, Russia

e-mail address: alex_pavlenko@inbox.ru

assoc.prof., PhD Galina Pavlenko

Department of Humanities

Faculty of Management

Taganrog Institute of Management and Economics

45,Petrovskaya street, 347900, Taganrog, Russia

e-mail address: galina21c@inbox.ru

assoc.prof., PhD Olga Stroganova

Institute of Humanities

Higher School of Foreign Languages

Peter the Great St. Petersburg Polytechnic University

29, Politekhnicheskaya street, 195251, St.Petersburg, Russia

e-mail address: stroganova.olga88@ gmail.com 